\title{
Pengelolaan Kegiatan Pengabdian Masyarakat dengan Sistem Informasi Manajemen
}

\author{
I Dewa Made Adi Baskara Joni ${ }^{1}$ I Putu Hendika Permana² \\ Program Studi Teknik Informatika, STMIK STIKOM Indonesia \\ Jl. Tukad Pakerisan 97 Denpasar, Bali \\ 1dewadi.414@gmail.com \\ ²dewankomisaris@gmail.com
}

\begin{abstract}
Abstrak
Kegiatan pengabdian kepada masyarakat merupakan salah satu kegiatan yang membutuhkan peran Teknologi Informasi (TI). Pemanfaatan TI memperkecil kemungkinan munculnya berbagai masalah dalam kegiatan. Dokumen seperti surat keputusan, surat tugas, proposal maupun laporan kegiatan seringkali tidak konsisten. Dalam evaluasi kegiatan juga memiliki banyak keterbatasan. Jika dibutuhkan informasi seperti siapa saja dosen yang terlibat dalam kegiatan, berapa total biaya untuk setiap kegiatan atau seluruhnya sangat sulit untuk diketahui. Sistem yang dibangun dapat membantu mengelola kegiatan pengabdian kepada masyarakat (PKM) baik PKM institusi maupun PKM kelompok dosen. Pengguna dapat mengelola periode di awal setiap pengajuan kegiatan PKM. Ketika dibutuhkan kelengkapan administrasi seperti Surat Keputusan dan Surat Tugas, dapat dihasilkan secara otomatis dari sistem. Dokumen proposal, laporan maupun bukti dokumentasi kegiatan dapat diunggah ke dalam sistem agar dapat diarsipkan secara digital dan terstruktur. Sistem diharapkan dapat menjadi solusi dari permasalahan yang dialami. Dengan sistem yang baru human error dapat diminimalisir dan pengelolaan kegiatan dapat dilakukan lebih mudah dengan bantuan $\mathrm{TI}$.
\end{abstract}

Kata kunci: Sistem, Sistem Informasi, Manajemen, pengabdian masyarakat.

\begin{abstract}
Community service activities is one activity that takes the role of Information Technology (IT). IT utilization minimize the possibility of the emergence of various problems in the activities. Documents such as decrees, letters of assignment, proposals and reports of activities is often inconsistent. In the evaluation of the activities also has many limitations. If the required information such as who the lecturer is involved in the activities, how much total cost for each activity or completely very hard to know. A system built to help manage community service activities (CS) both institutional and group of lecturers CS. Users can manage at the beginning of each submission period CS activity. When necessary administrative documents such as decree and Letter of Assignment, can be generated automatically from the system. The proposal documents, reports and documentation of evidence can be uploaded into the system in order to be archived digitally and structured. The system is expected to be a solution of the problems experienced. With the new system, human error can be minimized and management activities can be done more easily with the help of IT.
\end{abstract}

Keywords: System, Information System, Management, Community service.

\section{Pendahuluan}

Dewasa ini, setiap perguruan tinggi berlomba-lomba untuk meningkatkan kualitas. Peningkatan kualitas tersebut disebabkan oleh kebutuhan masyarakat terhadap pendidikan yang lebih baik. Masyarakat dalam hal ini calon mahasiswa memilih suatu perguruan tinggi atas dasar kepercayaan terhadap kualitasnya. Kualitas tersebut dapat dilihat dari nilai akreditasi, prestasi, karya ilmiah maupun eksistensi perguruan tinggi dan lulusannya di masyarakat. 
Sumber Daya Manusia (SDM) intelektual yang ada jika dikelola dengan baik dipastikan akan berdampak positif. Dampak yang diharapkan adalah terjadinya pembangunan secara berkesinambungan yang akan meningkatkan daya saing bangsa. Perguruan tinggi bertanggung jawab untuk mengambil peranan dalam pembangunan tersebut. Bentuk nyata peranan perguruan tinggi adalah dengan terselenggaranya tri dharma perguruan tinggi dengan baik dan benar.

Menurut Undang-Undang Republik Indonesia No. 12 Tahun 2012 tentang Pendidikan Tinggi, tridharma perguruan tinggi adalah kewajiban perguruan tinggi untuk menyelenggarakan pendidikan, penelitian dan pengabdian kepada masyarakat. Dengan demikian amanat undangundang wajib dijalankan sebaik-baiknya oleh seluruh civitas akademika. Salah satu cara untuk menjalankan kegiatan tri dharma dengan baik adalah dengan bantuan teknologi, khususnya teknologi informasi.

Pemanfaatan komputer sebagai media informasi telah memberikan peranan yang sangat penting dalam pembuatan suatu sistem yang aman dan lebih efisien. Ini adalah bukti dari perkembangan teknologi sehingga pengaksesan terhadap data atau informasi yang tersedia dapat berlangsung dengan cepat dan akurat. Perkembangan teknologi informasi dapat digunakan oleh banyak pihak, baik oleh perorangan ataupun suatu instansi di bidang pemerintahan, kesehatan, pendidikan, dan bisnis[1]. Dewasa ini banyak perguruan tinggi telah menerapkan TI dalam operasionalnya. Operasional yang dimaksud adalah kegiatan pendidikan, penelitian dan pengabdian masyarakat (tri dharma perguruan tinggi). Setiap komponen tri dharma perguruan tinggi tersebut memiliki kompleksitas yang berbeda. Tidak terkecuali dengan pengabdian masyarakat. Dari hasil pengamatan, jika kegiatan pengabdian masyarakat tidak menerapkan bantuan $\mathrm{TI}$ maka akan timbul berbagai masalah dalam pelaksanaan maupun evaluasi kegiatan.

Masalah yang muncul seperti administrasi kegiatan yang tidak tertata rapi. Dokumen seperti surat keputusan, surat tugas, proposal maupun laporan kegiatan seringkali tidak konsisten dan cenderung salah. Hal tersebut dapat terjadi disebabkan oleh proses penyusunan dokumen dilakukan secara manual yang mengakibatkan tingkat kesalahan (human error) menjadi tinggi. Setiap dokumen tersebut saling memiliki data yang terkait seperti misalnya nama-nama dosen yang muncul dalam surat keputusan harusnya sesuai dengan yang muncul pada surat tugas sampai pada laporan, namun pada kenyataannya sering terjadi kesalahan. Dalam penyusunannya kurang efisien karena harus menyusun dokumen tersebut satu per satu. Dengan menggunakan sistem berbasis komputer kemungkinan terjadinya kesalahan tersebut dapat diperkecil. Data dosen yang mengikuti kegiatan cukup dimasukkan sekali dan selanjutnya secara otomatis dapat dicetak dalam bentuk surat keputusan maupun surat tugas. Dalam evaluasi penyelenggaraan kegiatan juga memiliki banyak keterbatasan. Jika dibutuhkan informasi seperti siapa saja dosen yang terlibat dalam kegiatan, siapa dosen yang tidak ikut kegiatan dalam satu periode, berapa total biaya untuk setiap kegiatan atau seluruh kegiatan sangat sulit untuk diketahui.

Berdasarkan permasalahan diatas, maka dibutuhkan perbaikan pengeloaan agar dapat meningkatkan kinerja kegiatan pengabdian kepada masyarakat. Agar kegiatan dapat dikelola dengan baik dan terstruktur maka dibutuhkan suatu Sistem Informasi Manajemen (SIM). SIM pada dasarnya melibatkan proses mengumpulkan, mengolah, menyimpan, mengambil dan mengkomunikasikan informasi yang relevan untuk tujuan operasi manajemen yang efisien dan untuk perencanaan bisnis di organisasi manapun [2]. SIM tersebut akan menjadi suatu alat bantu (tools) dalam pengelolaan kegiatan pengabdian kepada masyarakat yang terintegrasi dengan baik. Sistem yang akan dibangun adalah berbasis web agar dapat dijalankan pada berbagai platform dan dapat diakses dari mana saja. Menurut [3], sistem berbasis web dapat melayani proses input data dan proses pencarian atau penelusuran data. Selain itu dengan adanya sistem informasi manajemen berbasis web tersebut dapat memudahkan segala pendataan di lembaga tersebut. Sistem informasi mempunyai peranan yang sangat penting di perusahaan dalam menyajikan informasi yang digunakan sebagai pengambilan keputusan pada perusahaan tersebut [4]. Untuk itu perlu dilakukan penelitian yang membangun suatu sistem informasi manajemen berbasis web dalam pengelolaan kegiatan pengabdian kepada masyarakat. Dengan adanya sistem tersebut diharapkan dapat meningkatkan kualitas kegiatan 
yang akan memberikan dampak positif terhadap pemberdayaan masyarakat dan pembangunan bangsa.

\section{Metodologi Penelitian}

Penelitian dilakukan dengan menganalisis, merancang dan membangun sistem informasi manajemen kegiatan pengabdian kepada masyarakat (PKM). Penelitian ini terbagi atas beberapa langkah yang dapat dilihat pada Gambar 1 berikut ini:

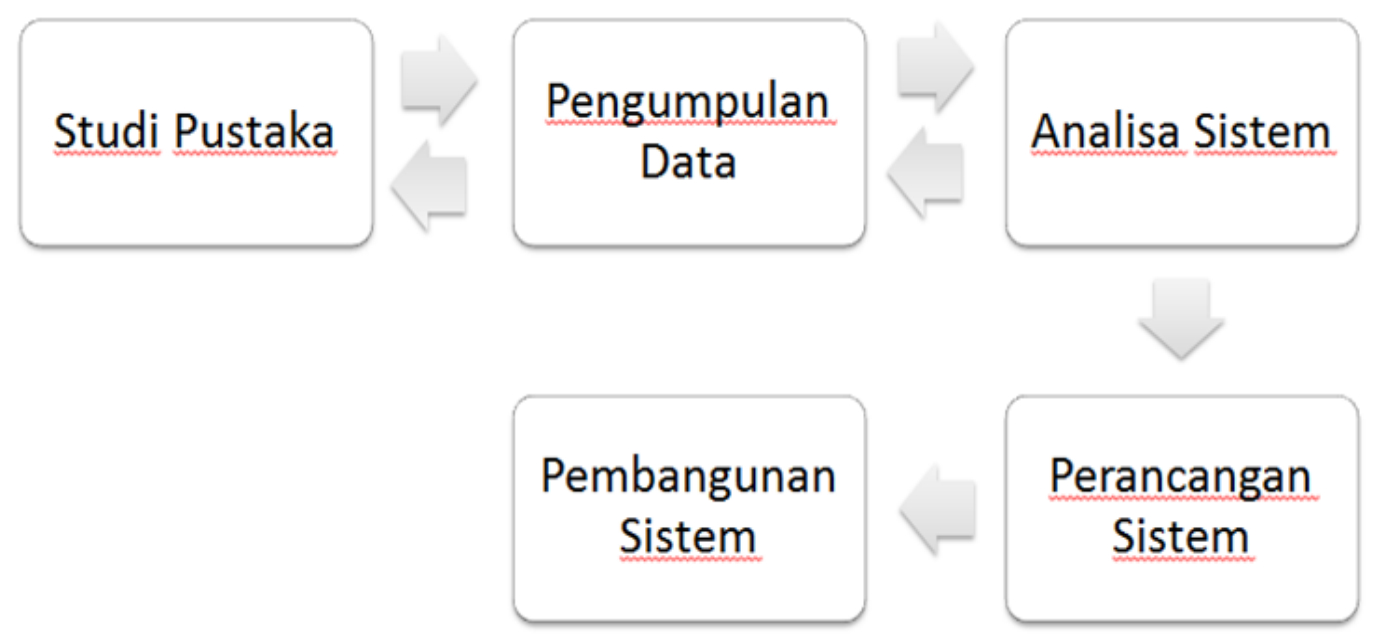

\subsection{Studi Pustaka}

Gambar 1. Metode Penelitian

Dalam penelitian ini digunakan beberapa referensi pendukung sebagai acuan dalam melakukan penelitian. Referensi tersebut berupa buku teks maupun jurnal dan prosiding. Buku teks digunakan sebagai dasar-dasar teori yang menjadi dasar dalam merancang dan membangun sistem yang dihasilkan dalam penelitian ini. Referensi jurnal dan prosiding dipergunakan untuk mempelajari penelitian-penelitian terkait dan terkini. Studi kepustakaan difokuskan pada referensi yang terkait dengan topik sistem informasi manajemen.

\subsection{Pengumpulan Data}

Dalam penelitian ini membutuhkan data agar pengembangan sistem dapat dilakukan dengan baik dan benar. STMIK STIKOM Indonesia (STIKI) khususnya Lembaga Penelitian dan Pengabdian Masyarakat (LPPM) menjadi studi kasus dalam penelitian ini. Pada tahap pengumpulan data, jenis dan sumber data yang dipergunakan adalah sebagai berikut:

a. Data Primer adalah data yang diperoleh langsung dari LPPM STIKI berupa data kegiatan pengabdian masyarakat.

b. Data Sekunder adalah data yang diperoleh dari studi kepustakaan seperti data hasil penelitian terdahulu dan data lain yang didapat dari buku, jurnal ilmiah, prosiding seminar dan lain sebagainya.

Teknik pengumpulan data yang dipergunakan dalam penelitian ini adalah studi dokumentasi. Studi dokumentasi adalah teknik pengumpulan data dengan mencari data yang ada dalam dokumen terkait, buku, internet atau jurnal yang berhubungan dengan penelitian ini. Dalam hal ini didapatkan dokumen-dokumen terkait seperti Surat Keputusan Kegiatan Pengabdian kepada Masyarakat, Surat Tugas, Proposal Pengabdian kepada Masyarakat, Laporan Pengabdian kepada Masyarakat beserta dokumentasi kegiatannya.

\subsection{Analisa Sistem}

Analisa sistem dalam penelitian ini akan dilakukan dalam dua tahap. Tahap pertama adalah analisa sistem yang sedang berlangsung saat ini (as-is) menggunakan Document Flow Diagram. Tahap kedua adalah analisa sistem baru yang dihasilkan dari penelitian ini (to-be) menggunakan System Flow Diagram. 


\section{A. Analisa Tahap Pertama}

Dalam analisa sistem tahap pertama akan digambarkan permasalahan yang terjadi, penyebab dan solusi yang dapat diterapkan untuk menyelesaikan permasalahan. Sistem pengelolaan kegiatan pengabdian kepada masyarakat secara umum akan terlihat pada analisa tahap pertama ini. Terdapat beberapa proses yang dianalisa sebagai berikut:

\section{Proses Pengajuan Kegiatan PKM}

Proses ini dimulai dari LPPM STIKI memulai periode kegiatan PKM. Secara jenis kegiatan, PKM dibagi menjadi dua yaitu kegiatan PKM Institusi dan kegiatan PKM kelompok dosen. Kegiatan PKM institusi secara pelaksanaan dikelola penuh oleh LPPM STIKI setiap semester sekali. Kegiatan PKM kelompok dosen dapat diajukan oleh dosen tetap STIKI secara berkelompok dan dapat melibatkan mahasiswa. Setelah proposal diajukan akan disahkan oleh LPPM dengan ditandatangani oleh Kepala LPPM. Setelah proposal dinyatakan siap akan diajukan kepada Ketua STIKI untuk diverifikasi. Selanjutnya proposal tersebut akan disetujui dan kegiatan PKM tersebut akan disahkan untuk dilaksanakan. Terakhir proposal yang telah disetujui tersebut akan diarsip oleh LPPM.

\section{Proses Pengelolaan Administrasi}

Proses dimulai dari LPPM menyusun dan membentuk panitia pelaksana kegiatan. Selanjutnya akan dituangkan dan diterbitkan dalam suatu Surat Keputusan (SK) pelaksanaan kegiatan PKM. Setelah SK tersebut dicetak, akan diajukan kepada Ketua STIKI untuk disahkan. Setelah SK yang telah disahkan tersebut diterima kembali LPPM, SK tersebut akan digunakan untuk menyusun Surat Tugas. Surat Tugas akan ditandatangani oleh Kepala LPPM dan selanjutnya akan diberikan kepada Kepala Program Studi dosen yang terlibat untuk diketahui dan ditandatangani. Selanjutnya surat tugas akan didistribusikan ke seluruh dosen yang terlibat dan akan diarsipkan LPPM.

\section{Proses Pengelolaan Laporan Kegiatan}

Proses dimulai dengan LPPM mengumpulkan dan merekapitulasi bukti-bukti kegiatan. Jika PKM institusi, laporan kegiatan akan disusun oleh LPPM dengan tanggung jawab dari ketua panitia kegiatan. Jika PKM kelompok dosen, laporan kegiatan akan disusun oleh kelompok dosen yang bersangkutan dengan tanggung jawab dari ketua kegiatan. Selanjutnya laporan yang telah disusun akan dicek kesesuaian proposal dengan hasil kegiatan. Jika tidak sesuai, akan diminta untuk memperbaiki laporan tersebut. Jika telah sesuai akan disahkan dan laporan tersebut akan diarsipkan LPPM.

\section{B. Analisa Tahap Kedua}

Dalam analisa tahap kedua ini akan dijelaskan kelebihan dari sistem yang baru dan akan berisi penjelasan mengenai manfaat untuk setiap fungsi yang ada. Secara umum dalam tahap analisa ini akan memberikan gambaran jelas mengenai sistem informasi manajemen yang dibangun dan diharapkan dapat menjadi solusi dari permasalahan yang terjadi.

\section{Proses Pengajuan Kegiatan PKM}

Proses dimulai dari LPPM menginputkan periode kegiatan yang berisi data periode yang bersangkutan kedalam sistem yang dibangun. Hal tersebut memungkinkan data yang terintegrasi dan meminimalisir human error ketika mengunggah proposal, laporan maupun bukti dokumentasi kegiatan. Proses penyusunan proposal sampai proposal tersebut disetujui tetap dilakukan secara offline (manual) sampai proposal tersebut disetujui. Proposal tersebut akan diunggah kedalam sistem melalui beberapa tahapan. Dimulai dari LPPM memilih periode kegiatan yang telah diinputkan sebelumnya. Selanjutnya akan dipilih jenis kegiatan PKM apakah PKM institusi atau PKM kelompok dosen. Jika PKM institusi, akan dipilih ketua panitia PKM saja dari data dosen yang tersedia. Jika PKM kelompok dosen, maka akan dipilih ketua beserta anggota kegiatan PKM yang telah ditentukan. Setelah data tersebut dimasukkan, akan diunggah proposal PKM yang telah disahkan kedalam sistem. 


\section{Proses Pengelolaan Administrasi}

Berdasarkan data proposal yang telah diunggah kedalam sistem, LPPM akan menentukan posisi kepanitiaan dan akan disimpan ke dalam database. Selanjutnya Surat Keputusan (SK) akan dicetak secara otomatis berisi data kepanitiaan yang sudah ditentukan tersebut untuk menghilangkan kemungkinan kesalahan. SK yang sudah dicetak tersebut akan disahkan oleh Ketua STIKI secara offline (manual). Setelah SK yang telah disahkan Ketua STIKI ditandai dengan tandatangan, Surat Tugas akan dicetak secara otomatis dari sistem dan akan diajukan untuk ditandatangani secara offline (manual) oleh Kepala Program Studi yang bersangkutan. Surat Tugas yang telah ditandatangani akan didistribusikan secara langsung kepada dosen yang terlibat dan akan diarsipkan.

\section{Proses Pengelolaan Laporan Kegiatan}

Proses dimulai dari LPPM mengumpulkan bukti-bukti kegiatan. LPPM akan memilih periode kegiatan yang telah diinputkan dan mengunggah bukti-bukti kegiatan tersebut. Proses penyusunan laporan tetap dilakukan secara offline (manual) oleh ketua panitia atau ketua pelaksana kegiatan. Setelah laporan dinyatakan sesuai, laporan akan disahkan dan siap untuk diunggah kedalam sistem. LPPM akan kembali memilih periode kegiatan yang bersangkutan dan mengunggah laporan kegiatan.

\subsection{Perancangan Sistem}

Proses-proses yang terkomputerisasi dan aliran data dari sistem yang dibangun akan di gambarkan menggunakan data flow diagram. Untuk rancangan database yang akan digunakan pada aplikasi digambarkan menggunakan entity relationship diagram.

\section{Data Flow Diagram - Level Konteks}

DFD level konteks menggambarkan sistem secara kontekstual. Pada level ini hanya terdapat satu proses dan external entities yang berinteraksi dengan sistem. Untuk lebih jelasnya, berikut dibawah ini pada gambar 2 adalah data flow diagram level konteks.

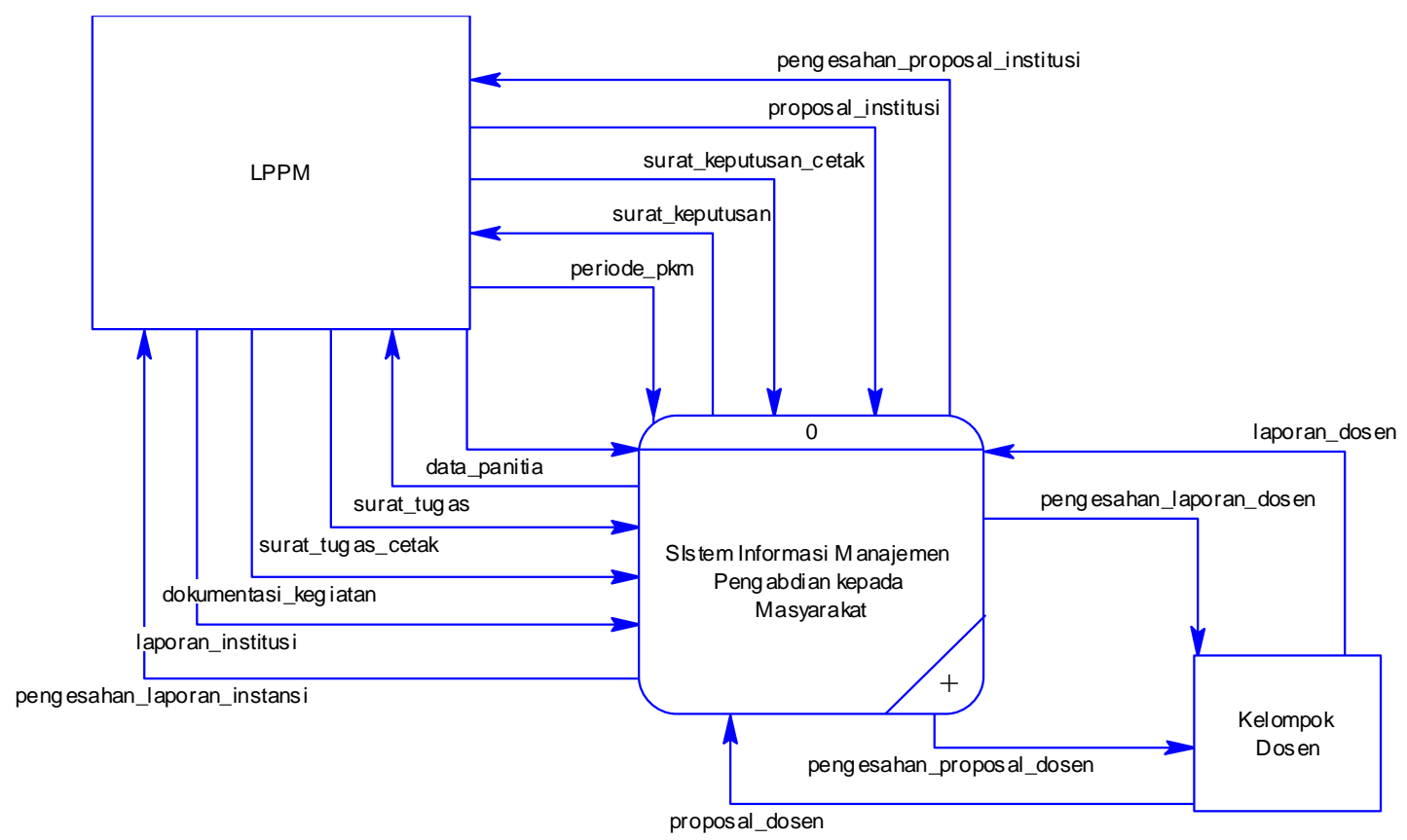

Gambar 2. Data Flow Diagram - Level Konteks

Pada Gambar 2 diatas dapat dilihat terdapat dua external entity. External entity Kelompok Dosen tidak berinteraksi secara langsung dengan sistem. Di dalam sistem ini Kelompok Dosen berpartisipasi dengan memberikan data proposal PKM dan data laporan PKM. Berdasarkan input tersebut maka Kelompok Dosen akan mendapatkan data pengesahan proposal dan laporan yang akan digunakan pada proposal dan laporan versi cetak (hard copy). Pada sistem, data tersebut akan diproses oleh LPPM. External entity LPPM berinteraksi dengan sistem untuk 
mengelola data periode, data panitia, data proposal PKM institusi, data laporan PKM institusi, data dukumentasi kegiatan, data surat keputusan dan surat tugas. Dari keseluruhan data tersebut, akan dikelola dalam 6 buah proses. Proses tersebut adalah input periode kegiatan PKM, pengelolaan panitia kegiatan, pengelolaan proposal PKM, pengelolaan laporan PKM, pengelolaan dokumentasi kegiatan dan pengelolaan administrasi.

2. Entity Relationship Diagram

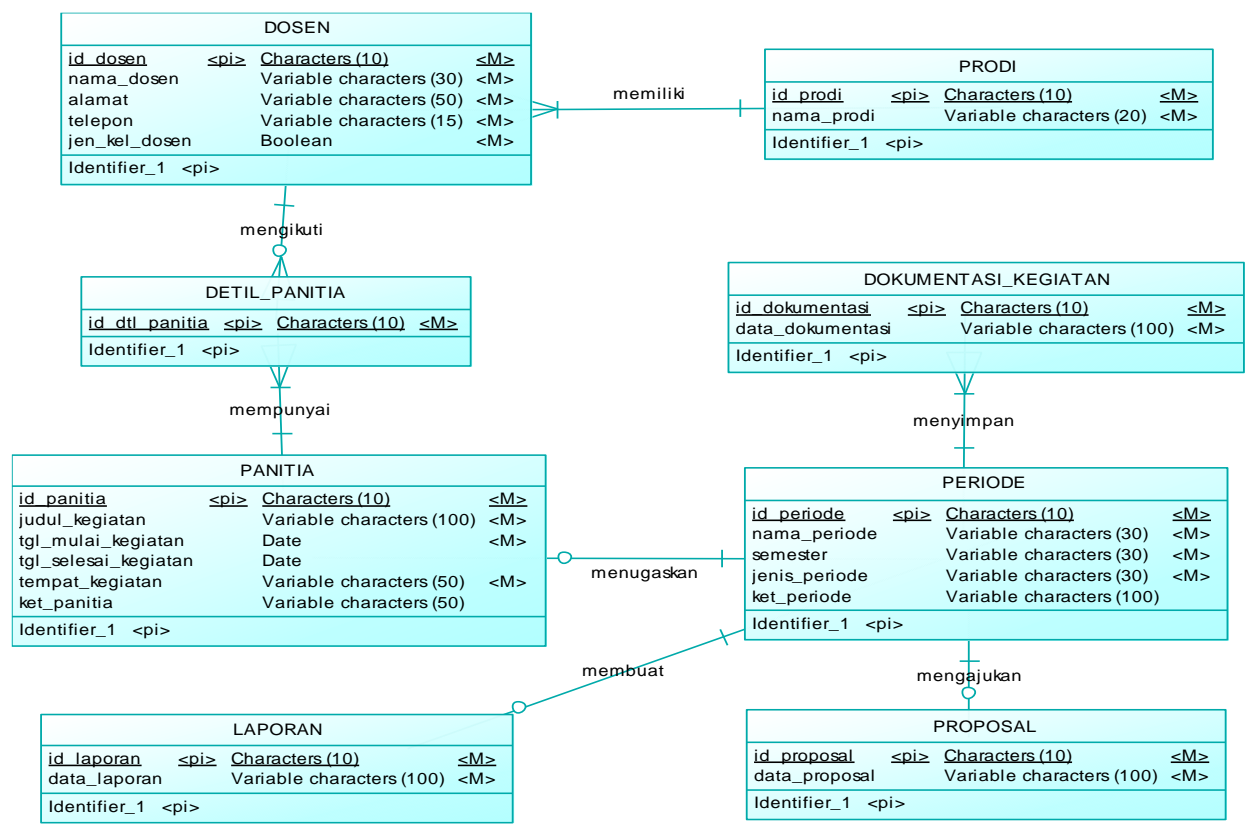

Gambar 3. Entity Relationship Diagram - Conceptual Data Model

Entity Relationship Diagram (ERD), merupakan hasil dari rancangan data store yang terdapat pada Data Flow Diagram (DFD). Dalam karya ilmiah ini akan disajikan ERD pada level Conceptual Data Model (CDM). Pada Gambar 3 diatas dapat dilihat adalah ERD-CDM dari Sistem Informasi Manajemen Pengabdian Masyarakat. Terdapat 8 tabel pada diagram ini yang saling berelasi. Relasi yang terbentuk ada dua yaitu one-to-one dan one-to-many.

\subsection{Kegiatan Manajemen}

Kegiatan manajemen berhubungan dengan tingkatannya di dalam organisasi. Manajemen dibagi menjadi manajemen tingkat atas, menengah dan bawah sehingga kegiatan dari setiap tingkatan manajemen itu adalah berbeda. Kegiatan dalam manajemen mempengaruhi pengolahan informasi, karena informasi yang dibutuhkan berbeda untuk masing-masing tingkatan manajemen. Kegiatan manajemen untuk masing-masing tingkatan tersebut dapat dikategorikan sebagai berikut: 1). Perencanaan strategis (strategic planning), merupakan kegiatan manajemen tingkat atas. 2). Pengendalian manajemen (management contro), merupakan kegiatan manajemen tingkat menengah. 3). Pengendalian operasi (operation control), merupakan kegiatan manajemen tingkat bawah.

\section{Hasil dan Pembahasan}

\subsection{Pengaturan Sistem}

Pada sistem yang dibangun, terdapat empat (4) menu pada pengaturan sistem. Menu tersebut adalah pengaturan Ketua Perguruan Tinggi, pengaturan Menyetujui, pengaturan Mengetahui dan pengaturan Periode. Pada pengaturan periode tersebut dapat ditambah, diubah dan non aktifkan data periode. Untuk menu pengaturan periode dapat dilihat pada Gambar 4 berikut. 


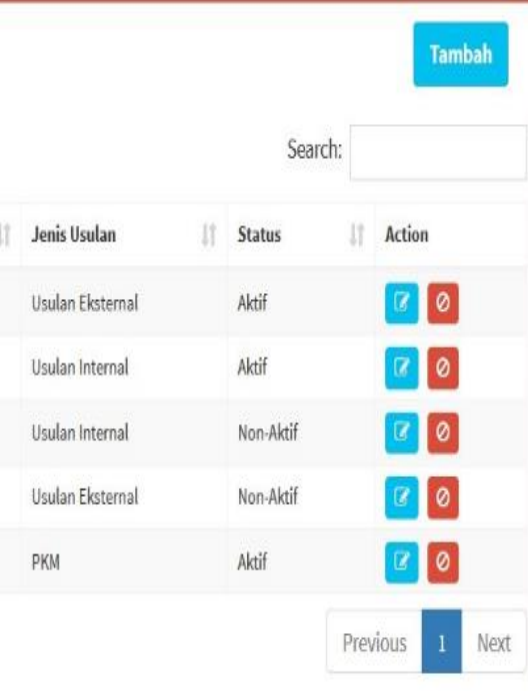

Gambar 4. Data Periode

\subsection{Pengelolaan Data Pengabdian Masyarakat}

Setelah dilakukan pengaturan sistem, selanjutnya dapat dikelola data kegiatan PKM. Pendataan PKM dimulai dari memilih periode dan selanjutnya memasukkan data proposal PKM. Setelah data dimasukkan akan terlihat pada daftar PKM yang dapat dilihat pada Gambar 5 di bawah. Ketika menekan tombol tambah, akan muncul form seperti pada Gambar 6 dan selanjutnya dapat mengisi data dan mengunggah dokumen proposal PKM. Setelah data PKM yang berisi proposal ini sudah diunggah, selanjutnya dapat mengunggah laporan PKM, bukti kegiatan PKM dan juga dapat mengelola data kepanitiaan yang akan secara otomatis dapat menghasilkan Surat Keputusan PKM berikut Surat Tugasnya.

No. II Periode If Semester If Ketua PKI

Judul

Tempat PKM

Tanggal Mulai if

Pelatihan Microsot office dan

1 2011/2012 Ganjil I Dewa Made Adi Baskara Pemanfaatan Internet Bagi Guru Taman Kanak-Kanak (TK). 
Gambar 5. Data PKM

Pada Gambar 5 di atas dan Gambar 6 di bawah dapat dilihat form yang akan digunakan untuk mengelola data PKM. Bila ingin mengunggah data laporan PKM dapat dilakukan dengan form pada Gambar 5 diatas. Pengguna dapat memilih dari daftar PKM yang tersedia, kemudian menekan tombol unggah. Setelah menekan tombol tersebut akan muncul form yang hampir sama dengan form pada Gambar 6. Perbedaannya hanya pada kolom "Proposal PKM" yang harus diisi dengan "Laporan PKM".

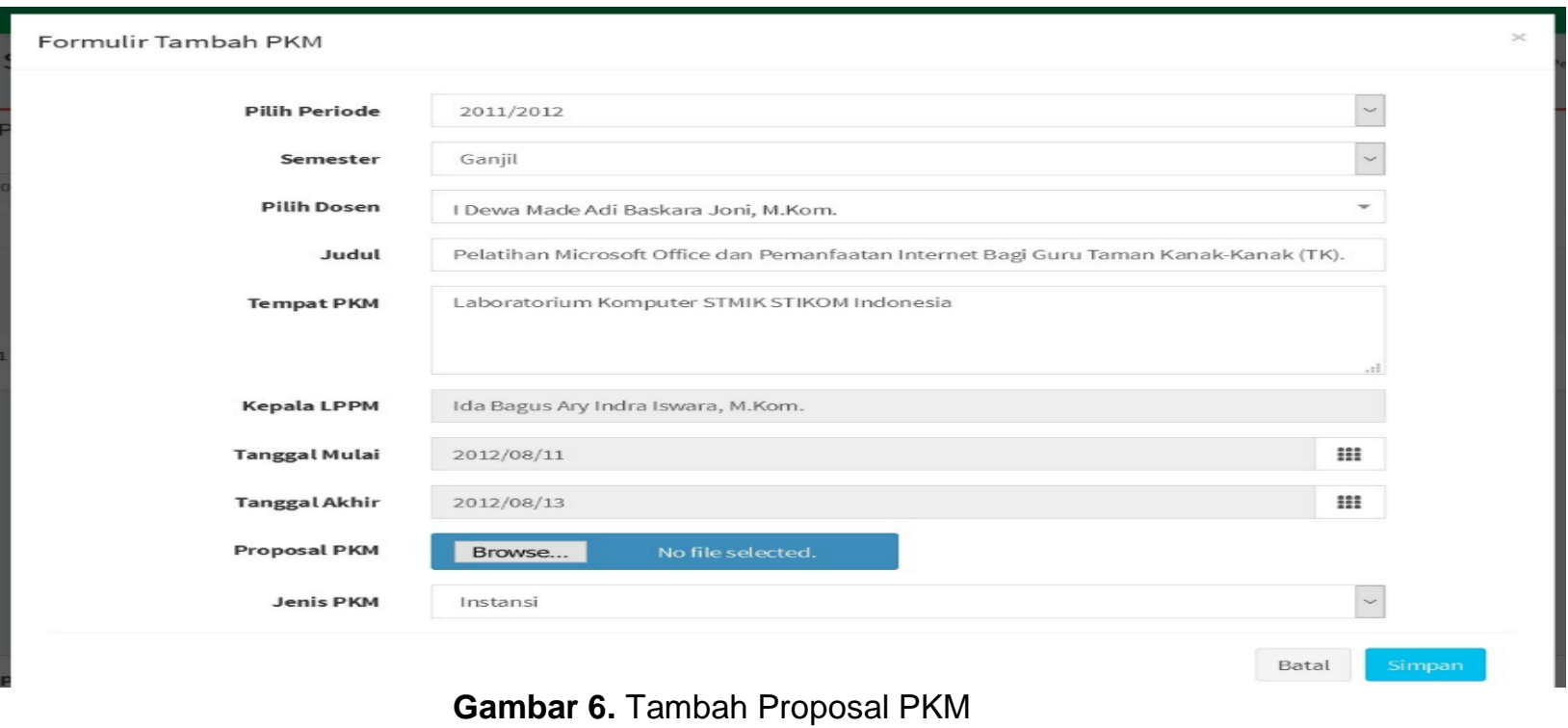

Ketika kegiatan PKM telah berlangsung, maka dokumentasi kegiatan dapat diunggah kedalam sistem. Pengguna tinggal memilih periode kegiatan dan memilih judul kegiatan yang akan diunggah dokumentasinya. Selanjutnya pengguna dapat memilih dokumentasi dan mengisi keterangan dari dokumentasi tersebut jika diperlukan. Jumlah dokumentasi untuk setiap kegiatan PKM yang dapat diunggah adalah tidak terbatas. Setelah selesai, dapat menekan tombol "Upload". Untuk lebih jelasnya, form untuk pengelolaan dokumentasi kegiatan dapat dilihat pada Gambar 7 berikut.

Bagian yang terpenting selanjutnya dalam sistem ini adalah pengelolaan data kepanitiaan. Untuk formasi kepanitiaan pada sistem ini dibuat dinamis. Pengguna dapat menambah dan menghapus formasi kepanitiaan terkait dosen yang bertugas dan perannya pada setiap kegiatan PKM. Hal tersebut diharapkan agar sistem dapat digunakan pada berbagai model kegiatan PKM. Untuk lebih jelasnya, form pengelolaan kepanitiaan dapat dilihat pada Gambar 8 di bawah. 


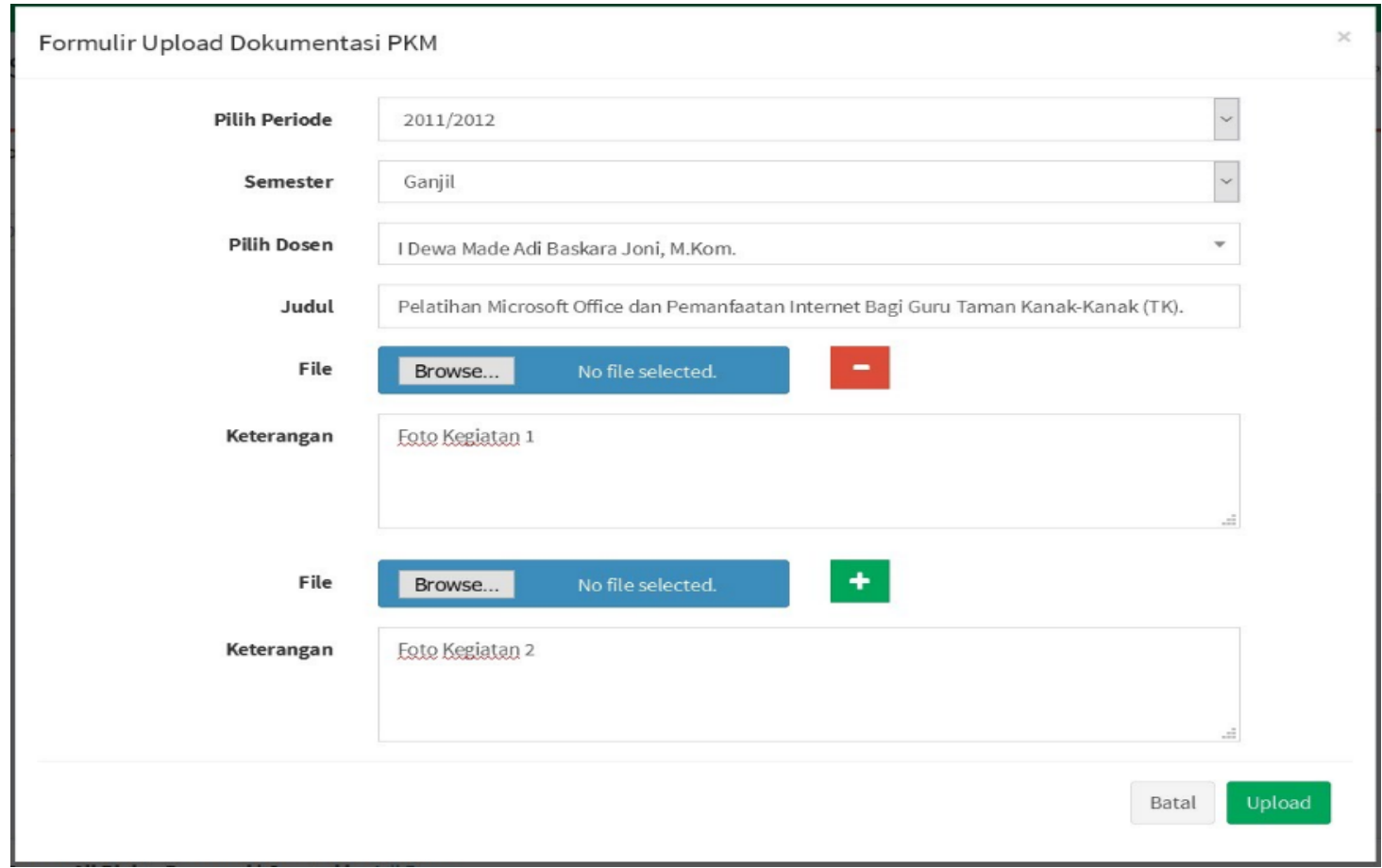

Gambar 7. Pengelolaan Dokumentasi Kegiatan

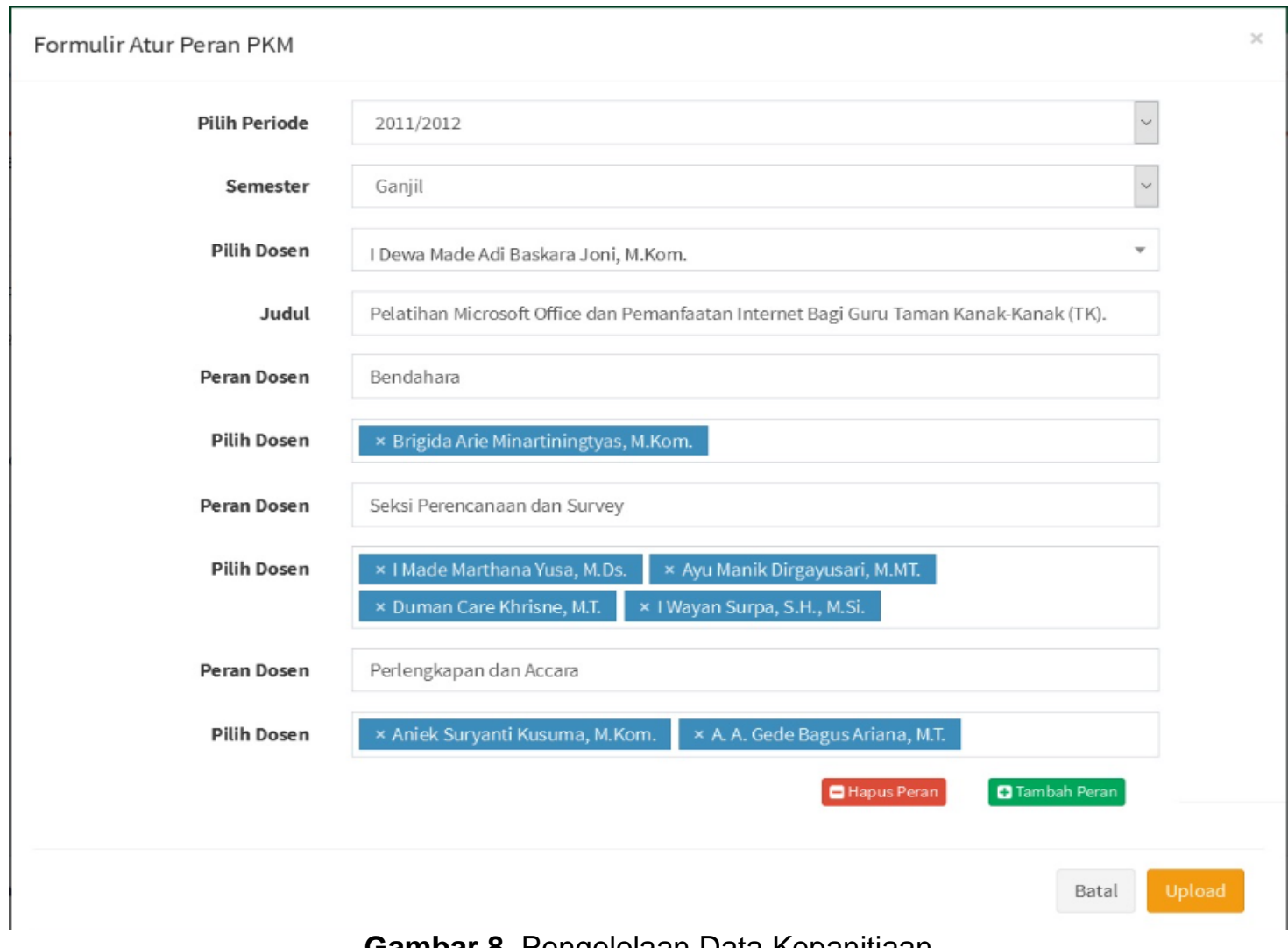

Gambar 8. Pengelolaan Data Kepanitiaan 


\section{Formulir Cetak PKM}

\begin{tabular}{|c|c|c|}
\hline Pilih Periode & $2011 / 2012$ & v \\
\hline Semester & Ganjil & 2 \\
\hline Pilih Dosen & I Dewa Made Adi Baskara Joni, M.Kom. & $\checkmark$ \\
\hline
\end{tabular}

Judul

Pelatihan Microsoft Office dan Pemanfaatan Internet Bagi Guru Taman Kanak-Kanak (TK).

Jenis Surat

\begin{tabular}{|l|l|}
\hline Surat Keputusan & \\
\hline Pilih Jenis Cetak & \\
\hline Surat Keputusan & \\
\hline Surat Tugas \\
\hline
\end{tabular}

Gambar 9. Formulir Cetak Surat

Salah satu kelengkapan administrasi yang penting dalam suatu kegiatan PKM adalah Surat Keputusan dan Surat Tugas. Pada sistem ini ketika sudah dilakukan input data PKM maka dapat dilakukan pengelolaan surat. Pengelolaan dapat dilakukan dengan menekan tombol cetak (simbol printer) yang ada pada Gambar 5. Setelah menekan tombol tersebut akan muncul form seperti yang terlihat pada Gambar 9 di atas. Berdasarkan kegiatan PKM yang telah dipilih, akan muncul periode dan judul PKM beserta pilihan jenis surat yang akan dicetak. Pengguna dapat memilih jenis surat yaitu Surat Keputusan (SK) atau Surat Tugas (ST). Selanjutnya pengguna dapat menekan tombol cetak, maka sistem akan menghasilkan SK dan ST sesuai dengan format dan data yang telah diinputkan.

\subsection{Analisa Pengembangan Sistem}

Pengelolaan kegiatan pengabdian kepada masyarakat yang ada dinilai masih belum efisien. Hal tersebut terjadi karena dalam prosesnya masih belum menggunakan sistem berbasis komputer terintegrasi. Sistem berbasis komputer diperlukan untuk memastikan integritas data dalam pengelolaan setiap kegiatan PKM. Pengelola kegiatan PKM dalam hal ini LPPM sering mengalami masalah mulai dari penyimpanan dokumen PKM yang kurang terstruktur sampai pada terjadinya data yang tidak valid dalam kelengkapan administrasi kegiatan. Pengelolaan proposal dan laporan berikut kelengkapan administrasi seperti surat keputusan dan surat tugas memiliki keterkaitan yang kongkrit pada setiap kegiatan. Penyimpanan bukti-bukti dokumentasi kegiatan masih menjadi masalah karena tidak tersimpan dengan baik pada suatu direktori khusus. Jika hal tersebut terus dibiarkan maka pengembangan kegiatan kearah yang lebih berkualitas cukup sulit dilakukan, karena informasi sulit didapatkan jika data yang diproses masih banyak terjadi kesalahan. Untuk itu dibutuhkan suatu solusi sistem informasi. Tugas medasar dari sistem informasi adalah mengumpulkan informasi, menyimpan informasi, memproses informasi, mentransmisi informasi dan menyajikan informasi.

Proses bisnis yang berjalan secara manual (tidak terkomputerisasi terintegrasi) telah dianalisa. Beberapa proses dikomputerisasi dan beberapa proses tetap dijalankan secara manual. Proses yang dikomputerisasi seperti pengarsipan dokumen proposal, laporan maupun dokumentasi kegiatan. Proposal dan laporan selain disimpan secara manual juga diunggah kedalam sistem sehingga sangat efisien dalam penyimpanan dan mudah untuk dicari. Surat keputusan dan surat tugas secara otomatis dapat dihasilkan sistem berdasarkan data pengajuan yang telah dibuat sebelumnya. Hal tersebut untuk memastikan tidak terjadi kesalahan dalam pembuatan dokumen administrasi tersebut. Proses yang tetap dilakukan manual seperti pengajuan tanda 
tangan kepada Ketua Perguruan Tinggi maupun Kepala Program Studi. Proses tersebut dapat dilakukan secara terkomputerisasi, namun dalam kasus ini belum dibutuhkan dan tetap akan dilakukan secara manual. Dengan menggunakan sistem baru yang berbasis komputer menyebabkan beberapa proses baru yang perlu dilakukan. Proses tersebut seperti proses mengelola user, mengelola program studi, mengelola data dosen maupun pengaturan sistem. Pihak LPPM harus menyiapkan pengelolanya untuk dapat beradaptasi dengan sistem yang baru. Jika dilihat dari dampak positif yang ditawarkan, sistem berbasis komputer dipandang menjadi solusi terbaik dalam masalah pengelolaan kegiatan PKM.

Sistem Informasi Manajemen Kegiatan Pengabdian Masyarakat ini merupakan kelanjutan dari sistem yang telah dibuat sebelumnya. Sistem ini dibuat terintegrasi dengan penelitian sebelumnya yang berjudul Sistem Informasi Manajemen Sebagai Alat Pengelolaan Penelitian Dosen [7]. Pengelolaan data dosen dan pengaturan sistem dapat dilakukan satu kali saja yang dapat berfungsi dengan baik pada kedua sistem. Dengan berjalannya kedua sistem yang terintegrasi tersebut, LPPM dapat mengelola kegiatan penelitian dan pengabdian kepada masyarakat dengan lebih baik. Diharapkan pengelolannya dapat lebih efektif sehingga dapat dihasilkan karya-karya ilmiah dosen yang lebih berkualitas. Efisiensi pengelolaan kegiatan juga menjadi harapan sehingga teknologi informasi dapat menjadi alat yang membantu LPPM dalam pekerjaannya.

\section{Kesimpulan}

Berdasarkan hasil penelitian yang telah dilakukan melalui perancangan, implementasi dan analisis dapat disimpulkan beberapa hal sebagai berikut: permasalahan pengelolaan kegiatan pengabdian masyarakat yang dilakukan secara manual adalah pada integritas data. Sering terjadi ketidakcocokan data pada kelengkapan administrasi kegiatan. Masalah lain adalah pada penyimpanan dokumen seperti proposal, laporan maupun dokumentasi kegiatan yang tidak terstruktur sehingga menyulitkan untuk mencarinya jika dibutuhkan. Pengelolaan dengan sistem berbasis komputer dititik beratkan pada pemrosesan data kegiatan pengabdian masyarakat yang terintegrasi. Fitur-fitur utama sistem yang ada seperti pengaturan pengesahan sistem, pengelolaan periode, pengelolaan panitia, unggah proposal, laporan dan dokumentasi kegiatan. Sistem secara otomatis akan menghasilkan surat keputusan dan surat tugas yang dapat dipastikan sesuai dengan data pengajuan kegiatan.

\section{Daftar Pustaka}

[1] D. Abdullah and C. I. Erliana, "PERANCANGAN SISTEM INFORMASI INVENTORI BARANG PADA CV. ILTIZAM COOPERATION," Syntax J. Inform., vol. 3, no. 1, 2014.

[2] Y. H. Al-Mamary, A. Shamsuddin, and N. A. Abdul Hamid, "The impact of management information systems adoption in managerial decision making: A review," Manag. Inf. Syst., vol. 8, no. 4, pp. 10-17, 2013.

[3] H. A. Hidayat, A. Wildan, and S. Apriliyanti, "ABDIMAS LPPM STMIK DCI," J. Manaj. Inform., vol. 4, no. 1, 2017.

[4] P. Bajdor and I. Grabara, "The Role of Information System Flows in Fullfiling Customers Individual Orders," J. Stud. Soc. Sci., vol. 7, no. 2, pp. 96-106, 2014. 